International Journal of Biology, Pharmacy and Allied Sciences (IJBPAS) 'A Bridge Betuen Caboratory and QRando'

WwW.iibpas.com

\title{
RECENT UPDATES IN DIABETES MELLITUS AND INSULIN RESISTANCE
}

\section{BLESSY PUSHPARATHNA $S^{\mathbf{1}}$, ANITHA ROY ${ }^{\mathbf{2}^{*}}$ AND MURALIDHARAN NP}

1: Research associate, Saveetha Dental College and Hospitals, Saveetha Institute of Medical and technical Sciences, Saveetha University, Chennai, India

2: Associate Professor, Department of Pharmacology, Saveetha Dental College and Hospitals, Saveetha Institute of Medical and technical Sciences, Saveetha University, Chennai, India

3: Associate Professor, Department of Microbiology, Saveetha Dental College and Hospitals, Saveetha Institute of Medical and technical Sciences, Saveetha University, Chennai, India

*Corresponding Author: E Mail: Dr. Anitha Roy: anitharov@saveetha.com

Received 19 ${ }^{\text {th }}$ March 2021; Revised 20 ${ }^{\text {th }}$ April. 2021; Accepted $19^{\text {th }}$ May 2021; Available online $1^{\text {st }}$ Aug. 2021 https://doi.org/10.31032/IJBPAS/2021/10.8.1025

\section{ABSTRACT}

Insulin resistance occurs when body cells do not respond to insulin properly so that blood glucose will be increased. This increases the potential of developing prediabetes which may eventually lead to type 2 diabetes. Prediabetes occurs in people with high insulin resistance. Around 1 in 3 people in the United States have prediabetes, according to figures from the Centers for Disease Control and Prevention (CDC). Insulin usually helps the body maintain a good balance of energy, therefore it is important to never allow the level of blood glucose to spike for too long. Insulin resistance can lead to several health issues like Acanthosis nigricans, Polycystic ovary syndrome (PCOS), increased risk of vascular diseases, such as heart disease etc. The risk factors for insulin resistance, prediabetes, and diabetes include obesity, a sedentary lifestyle or one that is low in exercise, smoking, sleep issues and high blood pressure. Several tests can help diagnose prediabetes and diabetes-like A1C test, Fasting blood glucose test and Random glucose test. Studies report that individuals can reduce the risk of type 2 diabetes by following some preventive lifestyle changes which 
primarily includes losing weight and increasing physical activity. Physical activities must be done regularly and healthful low carbohydrate diets must be followed as preventive measures. The most effective way to reduce insulin resistance is to make sustainable changes by altering our daily habits. The starting point for living well with diabetes is an early diagnosis. Regular screening tests for complications is also required. Easy access to basic diagnostics, such as blood glucose testing, should, therefore, be made available by the government in primary health care settings.

\section{Keywords: Diabetes; Insulin resistance; complications; etiology}

\section{INTRODUCTION}

Diabetes mellitus is a chronic nonperipheral vascular disease, and diminished communicable condition that results in high blood glucose levels. It is a complex metabolic disorder characterized by defective processing of blood sugar in our body. It is a condition primarily defined by the level of glucose giving rise to a risk of microvascular damage, retinopathy, nephropathy, neuropathy and other notable clinical conditions. $95 \%$ of the cases are type 2 diabetes requiring close monitoring of blood sugar levels regularly. It is estimated that 72.96 million adult population of India are diabetic [1]. According to the statistics of 2019 over 463 million adults of age ranging from 20 to 79 years are living with diabetes and it was predicted to rise to 700 million in 2030 [2, 3]. It is associated with reduced life expectancy, significant morbidity due to specific diabetes-related microvascular complications, increased risk of macrovascular complications leading to ischaemic heart disease, stroke and quality of life [4]. Therefore without undertaking careful management, diabetes can increase the risk of complications like stroke and heart disease [5]. Healthy eating and developing and maintaining active lifestyles can ward off this condition. Diabetes management is a large economic burden on society. It can increase the risks of other long term conditions if proper management of diabetes is taken [6]. The International Diabetes Federation (IDF) has concluded 14th of November each year as World Diabetes Day primarily to create global awareness due to its rapidly increasing numbers worldwide. This campaign acts as a platform to draw attention and reach a global audience of over 1 billion people in more than 160 countries [7].

Insulin is a peptide hormone produced by beta cells of the islets of Langerhans. It plays a central role in controlling blood sugar, breaking down the carbohydrates 
into sugar in the form of glucose. It helps in the transportation of glucose from the blood into the cells [8]. Insulin is essential for staying alive. Insulin resistance is a condition in which the body is resistant to insulin resulting in increased blood sugar. This affects the glucose balance and deteriorates the normal response of the body cells towards insulin [9]. There is a peak decrease in the entry of glucose into the cells paving way for its accumulation in the bloodstream. Insulin resistance is thus a major feature of prediabetes. Incase of Prediabetes the blood sugar is high, but not high enough to cause type 2 diabetes. It is a very common condition, more than 10 million cases are prediabetic in India. Physical inactivity is linked to prediabetes. Prediabetic people usually don't have any symptoms. Progression from prediabetes to type 2 diabetes is therefore not prominent. Proven lifestyle changes can prevent or delay prediabetes from developing into type 2 diabetes [10]. This article gives us a brief idea about the recent updates in diabetes mellitus and insulin resistance. Many hormones can induce insulin resistance including cortisol, growth hormone, and human placental lactogen.

\section{INSULIN RESISTANCE:}

\subsection{Molecular mechanisms of insulin resistance}

Diabetes is a complex metabolic disorder that defines a single etiological pathway. Accumulation of lipid metabolites, activation of unfolded protein response (UPR pathway) and innate immune pathways have all been implicated in the pathogenesis of insulin resistance [11]. The excess lipids are driven into alternate nonoxidative pathways which interns result in lipotoxicity and lipoapoptosis [12]. As the age goes up there is a gradual development of carbohydrate intolerance. This carbohydrate intolerance acts as a consequence of peripheral insulin resistance caused by a post-receptor defect in target tissue insulin action. Thus in elderly subjects, the severity of the abnormality in carbohydrate intolerance is directly associated with the degree of peripheral insulin resistance. There are various theories explaining insulin resistance, the new energy-based concept of insulin resistance states that insulin resistance is due to the surplus amount of energy in our cells. This is mediated by ATP via adenosine monophosphateactivated protein kinase signalling pathway. Decreasing the ATP level is a promising approach to treating insulin resistance according to this theory [13]. Thus weight loss exercise and calorie restriction reduce the ATP released by the insulin-sensitive cells. Recent studies demonstrated that a 
reduced strength of insulin signalling via the IRS-PI3-Kinase pathway results in diminished glucose uptake and utilisation in an insulin target tissue of an insulinresistant individual $[\mathbf{1 4}, \mathbf{1 5}]$. Other mechanisms include an imbalance between free radical production and antioxidant sensitivity leading to reduction of peripheral insulin sensitivity and contributing to insulin resistance [16].

\subsection{Etiology of insulin resistance}

Genetics, ageing and ethnicity play a vital role in developing insulin sensitivity. Primary factors behind it include obesity, belly fat, lack of excise, smoking and even lack of sleep. In skeletal muscles, it is manifested as reduced insulin-stimulated glycogen synthesis due to reduced glucose transport [17]. Candidate causal genes for insulin resistance were screened in human preadipocytes and adipocytes. Studies identified the Twelve genes which showed diverse phenotypes indicating differential roles in insulin sensitisation. This suggests the bridging mechanisms and the association of their genomic loci with insulin resistance. Short term best rest can induce insulin resistance in a person [18]. Some medications like corticosteroids, protease inhibitors and atypical antipsychotics are associated with insulin resistance. Many hormones including cortisol, growth hormone and human placental lactogen can induce insulin resistance. Acute or chronic inflammation, polycystic ovary syndrome and nonalcoholic fatty liver disease (NAFLD) can also be etiological factors of insulin resistance.

\subsection{Complications of insulin resistance}

Potential complications of insulin resistance include the development of cardiovascular diseases, renal diseases and ocular complications. Many patients do not develop diabetes even in extreme cases, to its contrast others develop multiple complications and people may be manifested with classic symptoms of diabetes mellitus such as polydipsia, polyuria, polyphagia and weight loss. During insulin resistance, several metabolic alterations induced the development of cardiovascular diseases. Insulin resistance can induce an imbalance in glucose metabolism that can lead to chronic hyperglycemia, which can trigger the oxidative stress and can cause an inflammatory response leading to cell damage [19]. Insulin resistance can alter a systematic lipid metabolism which leads to the development of dyslipidemia. This is often characterised by a well-known lipid triad [20]. Endothelial dysfunction due to insulin resistance paves way for atherosclerotic plaque formation [21]. In an insulin-resistant state, NO Synthesis is 
selectively impaired and the compensatory hyperinsulinemia may activate the MAPK pathway resulting in the elevation of blood pressure [22]. A killer complications associated with insulin resistance include diabetic retinopathy, papillopathy, cataract, glaucoma and ocular surface disease [23]. Insulin resistance also leads to diabetic renal complications like renal nephropathy [24]. Type 2 diabetes is primarily associated with liver disorders including liver cirrhosis, hepatic fibrosis [25], hepatocellular carcinoma and acute liver failure [26, 27]. As type 2 diabetes starts to prolong the body cells become less sensitive to insulin. This resulting insulin resistance is accompanied by inflammation [28] . These conditions can be treated if detected early and thus there is a possible decrease in risks due to insulin resistance.

\subsection{Clinical manifestations of insulin resistance}

Insulin resistance increases the risks of developing prediabetes which eventually leads to type 2 diabetes. Some do not develop diabetes even in extreme conditions. The primary condition includes obesity leading to raised BMI, which may be due to social demographic and lifestyle effects such as deprivation, smoking, ethnicity and gender [29]. Adipose tissue and peripheral tissue insulin resistance can generate pre-diabetes thus adipose tissue insulin resistance is a primary factor causing prediabetes [30]. It was demonstrated that thigh adipose tissue distribution is associated with insulin resistance in obesity and type 2 diabetes [31]. Metabolic syndrome is often associated with insulin resistance thus strength training and exercise may improve glucose sensitivity and reduce elevated insulin levels [32]. Other clinical conditions include polycystic ovary syndrome bracket (PCOS) [33], Acanthosis nigricans [34], linear and acral growth, hyperandrogenism and reproductive abnormalities [35].

\subsection{Psychological and economic aspects}

This can often lead to symptoms of depression leading to disruptions in the brain's ability to signal satiation exhibiting increased levels of anhedonia food and seeking behaviour [36]. Psychological insulin resistance phenomenon is often observed in type 2 diabetes patients with proper social support and management can reduce the complications. Dispelling the insulin myths, demonstrating the injection process, collaborative style and authoritative can act as key procedures to reduce psychological insulin resistance [37]. Insulin resistance is associated with high rates of cardiovascular diseases, thus hospitalisation and healthcare expenditure also comes into play. The impact of obesity also leads to economic burden [38]. 


\subsection{General Management of Diabetes}

Type 1 diabetes cannot be caused by insulin resistance but people with type 1 diabetes with insulin resistance will require large amounts of insulin doses to keep their blood sugar in control. Insulin resistance has been one of the reasons for suboptimal glycemic control in type 1 diabetes. These people are more prone to cardiovascular diseases and are usually obese. It is associated with the requirement of more insulin and further increased weight gain. It causes concerns about weight gain among teenagers psychologically. Hence prevention of weight gain by maintaining a proper diet and exercise is important. Thus long-term weight management should be considered in the treatment plan and methods to encounter microvascular diseases are often considered.

The management of type 2 diabetes hypoglycemic agents like sulphonylureas, meglitinides, biguanides, thiazolidinediones and alpha-glucosidase. If adequate control is not obtained by using a single therapeutic agent, physicians recommend therapy combining multiple oral hypoglycemic agents. Thus type 2 diabetes can be maintained by regular exercise, weight management, healthy eating, regular blood sugar monitoring and use of possible diabetes medication and insulin therapy [39-40].
Several oral hypoglycemic agents used for the treatment of diabetes are reported to have an adverse effect which includes severe liver damage, lactic acidosis and diarrhoea. Hence new plants are explored for their various pharmacological activities. Plants with cytotoxic effect are used for the treatment of cancer [41]. Research is being done to discover therapeutic agents with least side effects and has been a subject of great interest these years [42-45]. There are several hypoglycemic drugs in nanotechnology engineered to control diabetes [46]. It is an attractive field of science with controlled dispersity as well as possible clinical approaches and using natural sources as therapeutic agents. Recent approaches in drug discovery are based on Incretin mimetics, amylin analogues, gip analogues, peroxisome proliferator receptor [47]. Efforts are being made to educate the people about diabetes to reduce the impact of the disease. Health care professionals should be more active in spreading the knowledge about diabetes especially among the aged people [49].

\section{CONCLUSION}

Diabetes is a chronic, metabolic disease characterized by elevated levels of blood glucose which leads over time to serious damage to the heart, blood vessels, eyes, kidneys and nerves. The most common is type 2 diabetes which occurs when the 
body becomes resistant to insulin or doesn't synthesize enough insulin. Globally the number of people with diabetes mellitus has quadrupled in the past three decades and is the ninth major cause of death about 1 in 11 adults worldwide now have diabetes mellitus. The most common etiology of diabetes is due to insulin resistance. Controlling blood sugar level with oral medication or insulin is the main treatment. It is better to take preventive measures to avoid diabetes with proper exercise and diet.

\section{ACKNOWLEDGEMENT}

The authors would like to thank the editors and authors of the journal, which was the source of the scientific compilation of this review article.

\section{CONFLICT OF INTEREST: Nil}

\section{REFERENCES}

[1] Kaveeshwar SA, Cornwall J. The current state of diabetes mellitus in India. Australas Med J [Internet]. 2014 Jan 31;7(1):45-8. Available from:

http://dx.doi.org/10.4066/AMJ.2013 .1979

[2] Saeedi P, Petersohn I, Salpea P, Malanda B, Karuranga S, Unwin N, et al. Global and regional diabetes prevalence estimates for 2019 and projections for 2030 and 2045: Results from the International
Diabetes Federation Diabetes Atlas, 9th edition [Internet]. Vol. 157, Diabetes Research and Clinical Practice. 2019. p. 107843. Available from:

http://dx.doi.org/10.1016/j.diabres.2 019.107843

[3] Saeedi P, Salpea P, Karuranga S, Petersohn I, Malanda B, Gregg EW, et al. Mortality attributable to diabetes in 20-79 years old adults, 2019 estimates: Results from the International Diabetes Federation Diabetes Atlas, 9th edition [Internet]. Vol. 162, Diabetes Research and Clinical Practice. 2020. p. 108086. Available from: http://dx.doi.org/10.1016/j.diabres.2 020.108086

[4] Harding JL, Pavkov ME, Magliano DJ, Shaw JE, Gregg EW. Global trends in diabetes complications: a review of current evidence [Internet]. Vol. 62, Diabetologia. 2019. p. 3-16. Available from: http://dx.doi.org/10.1007/s00125018-4711-2

[5] Wylie-Rosett J, Hu FB. Nutritional Strategies for Prevention and Management of Diabetes: Consensus and Uncertainties. Diabetes Care [Internet]. 2019 May;42(5):727-30. Available from: 
http://dx.doi.org/10.2337/dci19-

0009

[6] Nasri H. On the occasion of the world diabetes day 2013; diabetes education and prevention; a nephrology point of view. J Renal Inj Prev [Internet]. 2013 Jun 1;2(2):31-2. Available from: http://dx.doi.org/10.12861/jrip.2013 .11

[7] Shaw JE, Sicree RA, Zimmet PZ. Global estimates of the prevalence of diabetes for 2010 and 2030 . Diabetes Res Clin Pract [Internet]. 2010 Jan;87(1):4-14. Available from:

http://dx.doi.org/10.1016/j.diabres.2 009.10.007

[8] Beals JM, DeFelippis MR, Paavola CD, Allen DP, Garg A, Bruce Baldwin D. Insulin [Internet]. Pharmaceutical Biotechnology. 2019. p. 403-27. Available from: http://dx.doi.org/10.1007/978-3030-00710-2_18

[9] Gao W, Wang W, Zhang J, Deng P, $\mathrm{Hu} \mathrm{J}$, Yang $\mathrm{J}$, et al. Allicin ameliorates obesity comorbid depressive-like behaviors: involvement of the oxidative stress, mitochondrial function, autophagy, insulin resistance and NOX/Nrf2 imbalance in mice [Internet]. Vol.
34, Metabolic Brain Disease. 2019.

p. 1267-80. Available from: http://dx.doi.org/10.1007/s11011019-00443-y

[10] Lu D-Y, Che J-Y, Yarla NS, Zhu H, Lu T-R, Xu B, et al. Type 2 Diabetes Study, Introduction and Perspective [Internet]. Vol. 8, The Open Diabetes Journal. 2018. p. 13-21. Available from: http://dx.doi.org/10.2174/1876524 601808010013

[11] Lei Z, Yang L, Yang Y, Yang J, Niu Z, Zhang X, et al. Activation of $\mathrm{Wnt} / \beta$-catenin pathway causes insulin resistance and increases lipogenesis in HepG2 cells via regulation of endoplasmic reticulum stress [Internet]. Vol. 526, Biochemical and Biophysical Research Communications. 2020. p. 764-71. Available from: http://dx.doi.org/10.1016/j.bbrc.20 20.03.147

[12] Ezhilarasan D, Lakshmi T, Nagaich U, Vijayaragavan R. Acacia catechu ethanolic seed extract triggers apoptosis of SCC25 cells [Internet]. Vol. 13, Pharmacognosy Magazine. 2017. p. 405. Available from: http://dx.doi.org/10.4103/pm.pm_ $458 \_16$ 
[13] Bartley C, Brun T, Oberhauser L, Grimaldi M, Molica F, Kwak BR, et al. Chronic fructose renders pancreatic $\beta$-cells hyperresponsive to glucose-stimulated insulin secretion through extracellular ATP signaling [Internet]. Vol. 317, American Journal of PhysiologyEndocrinology and Metabolism. 2019. p. E25-41. Available from: http://dx.doi.org/10.1152/ajpendo. 00456.2018

[14] Sangwung P, Petersen KF, Shulman GI, Knowles JW. Mitochondrial Dysfunction, Insulin Resistance, and Potential Genetic Implications [Internet]. Vol. 161, Endocrinology. 2020. Available from: http://dx.doi.org/10.1210/endocr/b qaa017

[15] Draznin B. Molecular Mechanisms of Insulin Resistance: Serine Phosphorylation of Insulin Receptor Substrate-1 and Increased Expression of p85 : The Two Sides of a Coin [Internet]. Vol. 55, Diabetes. 2006. p. $2392-$ 7. Available from: http://dx.doi.org/10.2337/db060391

[16] Cree-Green M, Bergman BC,
Cengiz E, Fox LA, Hannon TS, Miller $\mathrm{K}$, et al. Metformin Improves Peripheral Insulin Sensitivity in Youth With Type 1 Diabetes [Internet]. Vol. 104, The Journal of Clinical Endocrinology \& Metabolism. 2019. p. 3265-78. Available from: http://dx.doi.org/10.1210/jc.201900129

[17] Chen Z, Yu H, Shi X, Warren CR, Lotta LA, Friesen $\mathrm{M}$, et al. Functional Screening of Candidate Causal Genes for Insulin Resistance in Human Preadipocytes and Adipocytes [Internet]. Vol. 126, Circulation Research. 2020. p. 330-46. Available from: http://dx.doi.org/10.1161/circresah a.119.315246

[18] Dirks ML, Miotto PM, Goossens GH, Senden JM, Petrick HL, Kranenburg J, et al. Short-term bed rest-induced insulin resistance cannot be explained by increased mitochondrial $\mathrm{H} 2 \mathrm{O} 2$ emission [Internet]. Vol. 598, The Journal of Physiology. 2020. p. 123-37. Available from: http://dx.doi.org/10.1113/jp27892 0

[19] Ormazabal V, Nair S, Elfeky O, 
Aguayo C, Salomon C, Zuñiga

FA. Association between insulin resistance and the development of cardiovascular disease [Internet]. Vol. 17, Cardiovascular Diabetology. 2018. Available from:

http://dx.doi.org/10.1186/s12933018-0762-4

[20] Kihm L. Correction: Hypertension and Diabetic Nephropathy [Internet]. Vol. 124, Experimental and Clinical Endocrinology \& Diabetes. 2016. p. e4-e4. Available from: http://dx.doi.org/10.1055/s-00361585484

[21] Ciocoiu M, Bararu-Bojan I, Vladeanu M, Badescu C. The Renin-Angiotensin-Aldosterone System: Genomics, Proteomics and Therapeutic Implications [Internet]. Renin-Angiotensin System [Working Title]. 2019. Available from: http://dx.doi.org/10.5772/intechop en. 88170

[22] Zarei S, Saidijam M, Karimi J, Yadegarazari R, Farimani AR, Hosseini-Zijoud S-S, et al. Effect of resveratrol on resistin and apelin gene expressions in adipose tissue of diabetic rats [Internet].
Vol. 46, TURKISH JOURNAL OF MEDICAL SCIENCES. 2016. p. 1561-7. Available from: http://dx.doi.org/10.3906/sag1505-6

[23] Amini Z, Kafieh R, Mousavi E, Rabbani H. Diabetic retinopathy detection in ocular imaging by dictionary learning [Internet]. Diabetes and Fundus OCT. 2020. p. 343-78. Available from: http://dx.doi.org/10.1016/b978-012-817440-1.00013-9

[24] Bjornstad P, Cherney DZ. Insulin Resistance and the Kidney in Youth [Internet]. Contemporary Endocrinology. 2020. p. 221-35. Available from: http://dx.doi.org/10.1007/978-3030-25057-7_14

[25] Ezhilarasan D, Sokal E, Najimi M. Hepatic fibrosis: It is time to go with hepatic stellate cell-specific therapeutic targets [Internet]. Vol. 17, Hepatobiliary \& Pancreatic Diseases International. 2018. p. 192-7. Available from: http://dx.doi.org/10.1016/j.hbpd.2 018.04.003

[26] Gheena S, Ezhilarasan D. Syringic acid triggers reactive oxygen species-mediated cytotoxicity in HepG2 cells [Internet]. Vol. 38, 
Human \& Experimental

Toxicology. 2019. p. 694-702.

Available

from:

http://dx.doi.org/10.1177/0960327 119839173

[27] Ezhilarasan D. Oxidative stress is bane in chronic liver diseases: Clinical and experimental perspective [Internet]. Vol. 19, Arab Journal of Gastroenterology. 2018. p. 56-64. Available from: http://dx.doi.org/10.1016/j.ajg.201 8.03 .002

[28] Mehta M, Deeksha, Tewari D, Gupta G, Awasthi R, Singh H, et al. Oligonucleotide therapy: An emerging focus area for drug delivery in chronic inflammatory respiratory diseases [Internet]. Vol. 308, Chemico-Biological Interactions. 2019. p. 206-15. Available from: http://dx.doi.org/10.1016/j.cbi.201 9.05 .028

[29] Perry BI, Khandaker GM, Marwaha S, Thompson A, Zammit $\mathrm{S}$, Singh SP, et al. Insulin resistance and obesity, and their association with depression in relatively young people: findings from a large UK birth cohort [Internet]. Vol. 50, Psychological Medicine. 2020. p. 556-65.
Available

from:

http://dx.doi.org/10.1017/s003329 1719000308

[30] Wen J, Cai X, Zhang J, Jiang J, Li W, Liu G, et al. Relation of adipose tissue insulin resistance to prediabetes [Internet]. Vol. 68, Endocrine. 2020. p. 93-102. Available from: http://dx.doi.org/10.1007/s12020020-02186-8

[31] Goodpaster BH, Leland Thaete F, Kelley DE. Thigh adipose tissue distribution is associated with insulin resistance in obesity and in type 2 diabetes mellitus [Internet]. Vol. 71, The American Journal of Clinical Nutrition. 2000. p. 88592. Available from: http://dx.doi.org/10.1093/ajcn/71.4 .885

[32] Nolan CJ, Prentki M. Insulin resistance and insulin hypersecretion in the metabolic syndrome and type 2 diabetes: Time for a conceptual framework shift [Internet]. Vol. 16, Diabetes and Vascular Disease Research. 2019. p. 118-27. Available from: http://dx.doi.org/10.1177/1479164 119827611

[33] O’Brien B, Dahiya R, Kimble R. Hyperandrogenism, insulin 
resistance and acanthosis nigricans

(HAIR-AN syndrome): an extreme subphenotype of polycystic ovary syndrome [Internet]. Vol. 13, BMJ Case Reports. 2020. p. e231749. Available from:

http://dx.doi.org/10.1136/bcr2019-231749

[34] Chen ME, Hannon TS. Clinical Manifestations of Insulin Resistance in Youth [Internet]. Contemporary Endocrinology. 2020. p. 3-17. Available from: http://dx.doi.org/10.1007/978-3030-25057-7_1

[35] Yu JH, Kim HY, Kim SR, Ko E, Jin HY. Factors influencing psychological insulin resistance in type 2 diabetes patients. Int J Nurs Pract [Internet]. 2019 Jun;25(3):e12733. Available from: http://dx.doi.org/10.1111/ijn.1273 3

[36] Polonsky WH, Fisher L, Hessler D, Stuckey H, Snoek FJ, Tang T, et al. Identifying solutions to psychological insulin resistance: An international study [Internet]. Vol. 33, Journal of Diabetes and its Complications. 2019. p. 30714. Available from: http://dx.doi.org/10.1016/j.jdiacom p.2019.01.001
[37] Dall TM, Yang W, Gillespie K, Mocarski M, Byrne E, Cintina I, et al. The Economic Burden of Elevated Blood Glucose Levels in 2017: Diagnosed and Undiagnosed Diabetes, Gestational Diabetes Mellitus, and Prediabetes [Internet]. Vol. 42, Diabetes Care. 2019. p. 1661-8. Available from: http://dx.doi.org/10.2337/dc181226

[38] Sussman M, Benner J, Haller MJ, Rewers M, Griffiths R. Estimated Lifetime Economic Burden of Type 1 Diabetes [Internet]. Vol. 22, Diabetes Technology \& Therapeutics. 2020. p. 121-30. Available from: http://dx.doi.org/10.1089/dia.2019. 0398

[39] Kumar R. Management of Type 2 Diabetes in Frail and Elderly Patients [Internet]. Vol. 7, Current Research in Diabetes \& Obesity Journal. 2018. Available from: http://dx.doi.org/10.19080/crdoj.2 018.07.555705

[40] Wou C, Unwin N, Huang Y, Roglic G. Implications of the growing burden of diabetes for premature cardiovascular disease mortality and the attainment of the Sustainable Development Goal 
target 3.4 [Internet]. Vol. 9, Cardiovascular Diagnosis and Therapy. 2019. p. 140-9. Available from: http://dx.doi.org/10.21037/cdt.201 8.09.04

[41] Ashwini S, Ezhilarasan D, Anitha R. Cytotoxic Effect of Caralluma fimbriata Against Human Colon Cancer Cells [Internet]. Vol. 9, Pharmacognosy Journal. 2017. p. 204-7. Available from: http://dx.doi.org/10.5530/pj.2017. 2.34

[42] Menon S, Ks SD, Santhiya R, Rajeshkumar S, S VK. Selenium nanoparticles: A potent chemotherapeutic agent and an elucidation of its mechanism [Internet]. Vol. 170, Colloids and Surfaces B: Biointerfaces. 2018. p. 280-92. Available from: http://dx.doi.org/10.1016/j.colsurf b.2018.06.006

[43] Rajeshkumar S, Venkat Kumar S, Ramaiah A, Agarwal H, Lakshmi T, Roopan SM. Biosynthesis of zinc oxide nanoparticles usingMangifera indica leaves and evaluation of their antioxidant and cytotoxic properties in lung cancer (A549) cells [Internet]. Vol. 117, Enzyme and Microbial
Technology. 2018. p. 91-5. Available from: http://dx.doi.org/10.1016/j.enzmict ec.2018.06.009

[44] Karthiga P, Rajeshkumar S, Annadurai G. Mechanism of Larvicidal Activity of Antimicrobial Silver Nanoparticles Synthesized Using Garcinia mangostana Bark Extract [Internet]. Vol. 29, Journal of Cluster Science. 2018. p. 1233-41. Available from: http://dx.doi.org/10.1007/s10876018-1441-z

[45] Rajeshkumar S, Agarwal H, Venkat Kumar S, Lakshmi T. Brassica oleracea Mediated Synthesis of Zinc Oxide Nanoparticles and its Antibacterial Activity against Pathogenic Bacteria [Internet]. Vol. 30, Asian Journal of Chemistry. 2018. p. 2711-5. Available from: http://dx.doi.org/10.14233/ajchem. 2018.21562

[46] Anitha R, Ashwini S. Antihyperglycemic activity of Caralluma fimbriata: An In vitro approach [Internet]. Vol. 13, Pharmacognosy Magazine. 2017. p. 499. Available from: http://dx.doi.org/10.4103/pm.pm_ 
$59 \quad 17$

[47] Sharma P, Mehta M, Dhanjal DS, Kaur S, Gupta G, Singh H, et al. Emerging trends in the novel drug delivery approaches for the treatment of lung cancer. Chem Biol Interact [Internet]. 2019 Aug 25;309:108720. Available from: http://dx.doi.org/10.1016/j.cbi.201 9.06 .033

[48] Ezhilarasan D, Lakshmi T, Vijayaragavan R, Bhullar S, Rajendran R. Acacia catechu ethanolic bark extract induces apoptosis in human oral squamous carcinoma cells [Internet]. Vol. 8, Journal of Advanced Pharmaceutical Technology \& Research. 2017. p. 143. Available from:

http://dx.doi.org/10.4103/japtr.japt r_73_17

[49] Lakshmi T, Krishnan V,
Rajendran R, Madhusudhanan N. Azadirachta indica : A herbal panacea in dentistry - An update [Internet]. Vol. 9, Pharmacognosy Reviews. 2015. p. 41. Available from:

http://dx.doi.org/10.4103/09737847.156337

[50] Perumalsamy H, Sankarapandian K, Veerappan K, Natarajan S, Kandaswamy N, Thangavelu L, et al. In silico and in vitro analysis of coumarin derivative induced anticancer effects by undergoing intrinsic pathway mediated apoptosis in human stomach cancer [Internet]. Vol. 46, Phytomedicine. 2018. p. 119-30. Available from: http://dx.doi.org/10.1016/j.phymed .2018 .04 .021 